\title{
First Record of Biocontrol Agent Torymus sinensis (Hymenoptera; Torymidae) in Bosnia and Herzegovina
}

\author{
Dinka Matošević1 ${ }^{*}$, Osman Mujezinović ${ }^{2}$, Mirza Dautbašić ${ }^{2}$
}

(1) Croatian Forest Research Institute, Department for Forest Protection and Game Management, Cvjetno naselje 41, HR-10450 Jastrebarsko, Croatia; (2) University of Sarajevo, Faculty of Forestry, Chair for Forest and Urban Greening Protection, Wildlife and Hunting, Zagrebačka 20, BA-71000 Sarajevo, Bosnia and Herzegovina

* Correspondence: e-mail: dinkam@sumins.hr
Citation: MATOŠEVIĆ D, MUJEZINOVIĆ O, DAUTBAŠIĆ M 2017 First Record of Biocontrol Agent Torymus sinensis (Hymenoptera; Torymidae) in Bosnia and Herzegovina. South-east Eur for 8 (2): 147-149. DOI: https://doi.org/10.15177/ seefor.17-14

Received: 6 Oct 2017; Accepted: 12 Nov 2017; Published online: 24 Nov 2017

\begin{abstract}
Background and Purpose: Dryocosmus kuriphilus is an invasive insect species of sweet chestnut (Castanea spp.) originating from China, and the only effective control measure against this pest is classical biological control with introduced parasitoid Torymus sinensis. This parasitoid has been widely released in many European countries, but it also has the ability to rapidly spread naturally. No official releases have been done in Bosnia and Herzegovina.

Material and Methods: D. kuriphilus galls were collected in July 2017 on 6 localities in forest district Unsko (Una Sana canton) in Bosnia and Herzegovina. Presence and parasitism rates of $T$. sinensis were recorded in the entomological laboratory, Croatian Forest Research Institute. $T$. sinensis larvae were identified morphologically and by being compared with the voucher specimens.

Results and Discussion: Torymus sinensis larvae were positively identified in the examined $D$. kuriphilus galls from all localities in Bosnia and Herzegovina. Parasitism rates ranged from 44.83 to $74 \%$. Occurrence and high parasitism rates in Bosnia and Herzegovina observed in this study are not results of biocontrol releases of $T$. sinensis, but can be attributed to natural spread from Croatia. High parasitism rates observed in this study can indicate that the parasitoid was present in Bosnia and Herzegovina in 2016.

Conclusions: This study presents the first record of Torymus sinensis in Bosnia and Herzegovina. We predict that the parasitoid will continue its spread over Bosnia and Herzegovina in sweet chestnut forests and orchards and that it will act as effective biological control agent against $D$. kuriphilus.
\end{abstract}

Keywords: parasitoid, invasive species, Dryocosmus kuriphilus, natural spread, classical biological control, parasitism rate.

\section{INTRODUCTION}

Dryocosmus kuriphilus Yasumatsu (Hymenoptera; Cynipidae) is an invasive insect species, originating from China, which has spread in sweet chestnut (Castanea spp.) forests and orchards around the word [1]. In Europe, it has been first introduced to Italy [2] and from there it spread to the majority of European countries [1]. In Bosnia and Herzegovina D. kuriphilus was first recorded in 2015 in Una Sana canton [3]. D. kuriphilus is regarded as a serious threat to chestnuts, especially to fruit production [4] and crown leaf area loss [5]. Parasitoid Torymus sinensis Kamijo [Hymenoptera; Torymidae] has successfully been used as a classical biological control agent against $D$. kuriphilus and it has been released in biocontrol campaigns in Japan, the USA, Italy, France, Slovenia, Croatia and Hungary [6, 7, 8, 9, $10,11]$. Torymus sinensis is native to China, phenologically well synchronised with $D$. kuriphilus, it is highly specific, and lowers the outbreak levels of its host $[9,12,13]$. This parasitoid has shown high dispersal ability by being able to cover more than $70 \mathrm{~km}$ in only a few days aided by wind [13]. Croatia has done extensive biocontrol releases of $T$. sinensis since 2014, and apart from releases, the parasitoid has also rapidly spread from Italy over Slovenia to Croatia and has built a viable population with parasitism rates up to $90 \%[11,14]$. Based on this experience, we have expected 
T. sinensis to spread towards Bosnia and Herzegovina. Bosnia and Herzegovina has so far done no official releases of $T$. sinensis on its territory.

The aim of this paper is to report first record of biocontrol agent $T$. sinensis and its parasitism rates in sweet chestnut (Castanea sativa Mill.) forests of Bosnia and Herzegovina.

\section{MATERIALS AND METHODS}

D. kuriphilus galls were collected in July 2017 on 6 localities in forest district Unsko (Una Sana canton) in Bosnia and Herzegovina (Table 1). The galls were collected from randomly selected sweet chestnut trees from a height of 1.5-2.5 m. From each locality a sample of 100 galls was taken. Each gall from the sample was sliced open and examined under a binocular microscope Olympus SZX7 in entomological laboratory, Croatian Forest Research Institute. In dissected galls, larval chambers, the number of $T$. sinensis larvae, D. kuriphilus larvae and pupae (if present), and other parasitoid larvae were counted and parasitism rates were calculated: $P R=$ (the number of $T$. sinensis specimens/the number of $D$. kuriphilus larval chambers) $\times 100(\%)$. T. sinensis larvae were identified morphologically $[11,15]$ and by being compared with the voucher specimens deposited at the Department for Forest Protection, Croatian Forest Research Institute. The larvae were stored in absolute ethanol at $-20^{\circ} \mathrm{C}$ in entomological laboratory, Croatian Forest Research Institute, for further analyses.

\section{RESULTS AND DISCUSSION}

Torymus sinensis larvae were positively identified in examined $D$. kuriphilus galls from all six localities. Parasitism rates ranged from 44.83 to $74 \%$ (Table 1 ).

The results of our study show presence of $T$. sinensis in Bosnia and Herzegovina. Occurrence and high parasitism rates in Bosnia and Herzegovina observed in this study (Table 1 ) are not results of biocontrol releases of $T$. sinensis, but can be attributed to natural spread $[13,14]$. This biocontrol agent spread naturally from Croatia over interconnected sweet chestnut forests and wooded chestnut patches bordering Croatia and Bosnia and Herzegovina in Una Sana canton. It has already been documented that $T$. sinensis is rapidly spreading naturally eastwards from Italy all over Croatia [14]. This rapid natural spread was additionally assisted by releases from laboratory rearing in Croatia in the area near the border with Bosnia and Herzegovina in 2016 and 2017 [14]. High parasitism rates observed in this study can indicate that the parasitoid was present in Bosnia and Herzegovina in 2016, but was not sampled and identified. We predict that the parasitoid will continue its spread over Bosnia and Herzegovina in sweet chestnut forests and orchards and that it will act as effective biological control agent against $D$. kuriphilus, lowering its population and damages in sweet chestnut forests.

\section{Acknowledgments}

Dinka Matošević would like to thank Blaženka Ercegovac and Ivana Mihaljević for laboratory work.

TABLE 1. Localities, coordinates and parasitism rates of Torymus sinensis for the samples taken in Una Sana canton, Bosnia and Herzegovina, in 2017.

\begin{tabular}{llc}
\hline Locality name (management unit/compartment/locality) & WGS coordinates $\mathbf{( x ;} \mathbf{y})$ & Torymus sinensis parasitism rates (\%) \\
\hline Gomila/54/Projsa & 15,$960596 ; 44,979998$ & 44.83 \\
Gomila/61/Pivnice & 15,$995468 ; 45,001145$ & 53.75 \\
Baštra-Ćorkovača/50/Ćorkovača & 16,$143863 ; 45,060535$ & 51.98 \\
Glinica/22/Radoč & 16,$118054 ; 45,078491$ & 61.64 \\
Glinica/46/Zaradostovo & 16,$062802 ; 45,074912$ & 65.43 \\
Kladušnica/24/Šiljkovača & 15,$785067 ; 45,150493$ & 74.00 \\
\hline
\end{tabular}

\section{REFERENCES}

1. CABI 2017 Dryocosmus kuriphilus. In: Invasive species compendium. URL: https://www.cabi.org/isc/datasheet/20005 (10 September 2017).

2. BRUSSINO G, BOSIO G, BAUDINO M, GIORDANO R, RAMELLO F, MELIKA G 2002 Dangerous exotic insect for the European chestnut. Informatore Agrario 58 (37): 59-61

3. DELALIC Z 2016 Prvi nalaz karantinske štetočine kestenove ose šiškarice (Drycosmus kuriphilus) u Bosni i Hercegovini. Biljni Lekar 44 (1): 58-65
4. BATTISTI A, BEVEGNU I, COLOMBARI F, HAACK RA 2013 Invasion by the chestnut gall wasp in Italy causes significant yield loss in Castanea sativa nut production. Agr For Entomol 16 (1): 75-79. DOI: https://doi.org/10.1111/afe.12036

5. GEHRING E, BELLOSI B, QUACCHIA A, CONEDERA M 2017 Assessing the impact of Dryocosmus kuriphilus on the chestnut tree: branch architecture matters. J Pest Sci. DOI: https://doi.org/10.1007/ $\underline{\text { s10340-017-0857-9 }}$ 
6. MORIYA S, SHIGA M, ADACHI I 2003 Classical biological control of the chestnut gall wasp in Japan. In: van Driesche RG (ed) Proceedings of the 1st international symposium on biological control of arthropods, USDA Forest Service, Washington, pp 407415

7. COOPER WR, RIESKE LK 2011 A native and an introduced parasitoid utilize an exotic gall-maker host. BioControl 56 (5): 725-734. DOI: https://doi.org/10.1007/s10526-011-9350-1

8. BOROWIEC N, THAON M, BRANCACCIO L, WAROT S, VERCKEN E, FAUVERGUE X, RIS N, MALAUSA JC 2014 Classical biological control against the chestnut gall wasp Dryocosmus kuriphilus (Hymenoptera, Cynipidae) in France. Plant Protection Quarterly 29 (1): 7-10

9. MATOŠEVIĆ D, QUACCHIA A, KRISTON É, MELIKA G 2014 Biological Control of the Invasive Dryocosmus kuriphilus (Hymenoptera: Cynipidae) - an Overview and the First Trials in Croatia. South-east Eur for 5 (1): 3-12. DOI: https://doi.org/10.15177/seefor.14-05

10. FERRACINI C, GONELLA E, FERRARI E, SALADINI MA, PICCIAU L, TOTA F, PONTINI M, ALMA A 2015 Novel insight in the life cycle of Torymus sinensis, biocontrol agent of the chestnut gall wasp. BioControl 60 (2): 169-177. DOI: https://doi.org/10.1007/s10526$\underline{014-9633-4}$
11. MATOŠEVIĆ D, LACKOVIĆ N, MELIKA G, KOS K, FRANIĆ I, KRISTON E, BOZSO M, SELJAK G, ROT M 2015 Biological control of invasive Dryocosmus kuriphilus with introduced parasitoid Torymus sinensis in Croatia, Slovenia and Hungary. Periodicum Biologorum 117 (4): 471-477

12. QUACCHIA A, MORIYA S, BOSIO G, SCAPIN I, ALMA A 2008 Rearing, release and settlement prospectin Italy of Torymus sinensis, the biological control agent of the chestnut gall wasp Dryocosmus kuriphilus. BioControl 53 (6), 829-839. DOI: https:// doi.org/10.1007/s10526-007-9139-4

13. COLOMBARI F, BATTISTI A 2016 Spread of the introduced biocontrol agent Torymus sinensis in north-eastern Italy: dispersal through active flight or assisted by wind? BioControl 61 (2): 121139. DOI: https://doi.org/10.1007/s10526-015-9712-1

14. MATOŠEVIĆ D, LACKOVIĆ N, KOS K, KRISTON E, MELIKA G, ROT M, PERNEK M 2017 Success of classical biocontrol agent Torymus sinensis within its expanding range in Europe. J Appl Entomol 141 (9): 758-767. DOI: https://doi.org/10.1111/jen.12388

15. GÓMEZ JF, NIEVES-ALDREY JL, NIEVES MH 2008 Comparative morphology, biology and phylogeny of terminal-instar larvae of the European species of Toryminae (Hym., Chalcidoidea, Torymidae) parasitoids of gall wasps (Hym. Cynipidae). Zool J Linn Soc-Lon 154 (4): 676-721. DOI: https://doi.org/10.1111/i.10963642.2008.00423.x 